\title{
MAKING ENGINEERING DEPARTMENTS ENTREPRENEURIAL: A DISCUSSION!
}

UDC: 005.511:[378.6:62

Original Scientific Paper

\author{
Zelimir William TODOROVIC ${ }^{1}$, Jun Ma TODOROVIC \\ ${ }^{1}$ Purdue University Fort Wayne, 2101 E Coliseum Blvd, Indiana, USA \\ E-mail: todorovz@pfw.edu
}

Paper received: 29.03.2019.; Paper accepted: 18.04.2019.

\begin{abstract}
The concept of an "entrepreneurial orientation" is well established in the literature on the strategic posture of firms. Increasingly, large organizations are also turning to entrepreneurship in their efforts to become flexible and respond to pressures to "do more with less". To understand what it means for engineering departments to be "entrepreneurial", interviews with forty faculty members explored this issue. Transcripts of the interviews were analysed using content analysis software. Next, focus groups were employed to identify and establish face validity for the items developed. The results suggest risk-taking is the most important dimension in developing an entrepreneurial engineering department, and a strong requirement for its continued competitiveness. Further, study also supports the notion that entrepreneurial engineering faculty will develop higher levels of Industry collaboration, funding and reputation - leading to higher success for internal university stakeholders.
\end{abstract}

Key words: University entrepreneurship, Entrepreneurial orientation, University department.

\section{INTRODUCTION}

It is widely recognized that today's contemporary environment is dynamic - exhibiting a high rate of change in response to global competition and the application of new technologies (Association of Universities and Colleges of Canada, 2001b; Etemad \& Wright, 1999; Hernandez-Gantes, Sorensen, \& Nieri, 1996; Liu, 2017; Mudalige, Noor Azizi, \& Marlin Abdul, 2018; Paweta, 2015). Consequently, public attention has increasingly focused towards the effective and fiscally responsible management of public institutions. The recent explosion of entrepreneurial activity (National Governors Association, 2000), and the prominent role of knowledge in the "new economy" (Krabel, 2018) has prompted a shift in expectations about the role of universities toward an emphasis on research commercialization and contribution to economic development. Today's universities are expected to contribute to their communities above and beyond research alone, providing guidance, training and expertise. Going forward, an examination of literature is followed by study's method section. Thereafter the findings section is followed by discussion and conclusion sections.

\section{LITERATURE REVIEW}

A focused stream of research on the concept of "entrepreneurial orientation" clearly establishes that large organizations can benefit from doing things in an entrepreneurial manner. The study of Entrepreneurial Orientation (EO) has its roots in the field of strategy research, especially the writings of Mintzberg (Mintzberg, 1973) and Miles and Snow (Miles \& Snow, 1978). Mintzberg identified three strategy types; entrepreneurial, planning, and adaptive, while Miles and Snow (Miles \& Snow, 1978) wrote about "prospector firms" and the role that an entrepreneurial approach to strategy plays when firms are faced with decision such as what products to offer or markets to enter. Building on these early references towards an entrepreneurial approach to strategy, Miller (Miller, 1983) was one of the first to describe the components of the approach. He defined an entrepreneurial firm as one that "engages in product marketing innovation, 
undertakes somewhat risky ventures, and is first to come up with proactive innovations (p. 771)." Later, Morris and Paul (Morris\& Paul, 1987) refined this definition: EO is the "inclination of top management to take calculated risks, to be innovative, and to demonstrate proactiveness."

The dimensions of EO (innovation, risk-taking, proactiveness) can provide an organization with entrepreneurial or Schumpeterian rent by allowing it to profit from more risk-intensive activities (Lee \& Slater, 2007; Mishra, 2017). Thus, entrepreneurial orientation serves to integrate and focus resources, potentially resulting in (or enhancing) a competitive advantage. EO is associated with improved performance in private sector corporations (Lekmat et al., 2018; Liet al., 2008; Mishra, 2017; Wiklund, 1999). Further, public sector managers have also found entrepreneurship to be a "salient concept for their organizations, and that the key obstacles to its implementation are very similar to those reported by corporate managers" (Morris \& Jones, 1999).

The literature contains evidence that even within the private sector the dimensions of EO can vary in their importance and relationship to each other in complex ways (Richard et al., 2004). For example, Kropp et al. (2008) found that the decision to start an international new venture is positively related to the proactiveness and risk-taking components of $\mathrm{EO}$, while the innovativeness component is not an important factor. Naldi et al. (2007) found that the three dimensions differentially impact the performance of family owned firms. In particular, family firms take fewer risks than do non-family firms. Indeed, Naldi's findings show that risktaking in family firms is negatively related to their performance. Coulthard (2007) reviewed four Australian industry studies and found positive correlations between performance and the dimensions of innovativeness and proactiveness, while dimensions of competitive aggression, risktaking, and autonomy varied in their importance between sectors and over time. These studies and others suggest that the influence of EO is contextual. In addition, the original ENTRESCALE was developed using a relatively small sample of large U.S. and Canadian corporations. Thus, it is prudent to question use of this scale in different organizational contexts, especially ones as distinctive as public universities.

For example, a university that is innovative, proactive and able to take risks will develop internal routines supporting these characteristics. Strategy and strategic orientation were associated with firm based routines in past research (Morgan \& Strong, 2003; Schneider, Wheeler, \& Cox, 1992). A university that is entrepreneurially oriented may be more open to co-operation with private sector firms (Bonaccorsi \& Piccaluga, 1994), possibly leading to more university-industry technology transfer (Behn, 1998).

\section{Entrepreneurship at Universities}

Declines in per-student government funding, calls for increased accountability, and a focus by governments on the commercialization of research, are forces influencing many public universities to seek more innovative and "entrepreneurial" approaches to diversify revenue and contain costs (Box, 1999). Calls for increased commercialization of university research have become louder, even from within the university sector (Agrawal, 2001; Association of Universities and Colleges of Canada, 1998, 2001a, 2001b; Conceicao, Heitor, \& Oliveira, 1998; Expert Panel on the Commercialization of University Research, 1999). Likewise, collaborative efforts between academia, government, and industry are seen as vital for the regional technology development (Johnson, 2008). Commercialization and technology transfer are seen as a way to increase the benefits of universities to the public (Expert Panel on the Commercialization of University Research, 1999), and to help fill the funding gap left by reduced government funding (Association of Universities and Colleges of Canada, 2001a). This gap is often supplemented through revenue sharing with inventors, or patent-based royalties (Baldini, 2010).

Historically, technology transfer by a given university was almost exclusively through the patenting and licensing the results of university research (Association of Universities and Colleges of Canada, 2001a, 2001b; Association of University Technology Managers, 2000; Berggren \& Dahlstrand, 2009; Bonaccorsi \& Piccaluga, 1994; Johnson \& Tilley, 1999; Macho-Stadler, Pérez-Castrillo, \& Veugelers, 2008; Migliori et al., 2017; Nosella \& Grimaldi, 2009; van Burg et al., 2008). However, more recently universities have played a direct role in venture start-ups (Bray \& Lee, 2000; Miranda et al., 2017; Mustar \& Wright, 2010; Steffensen et al., 2000), establishing business incubators (Kolympiris \& Klein, 2017; Lasrado et al., 2016; Mian, 1994, 1996, 1997; 
Stevenson \& Thomas, 2001), and encouraging university-based consulting (Perkmann \& Walsh, 2008; Rainsford, 1992; Wolf, 2017). The Canadian government continues to emphasize and support commercialization efforts of Canadian universities (Rasmussen, 2008). Researchers who collaborate with practitioners are found to have significantly superior research performance compared to researchers who do not engage in such collaboration (Abramo et al., 2009). Some universities combine these activities with their education efforts, resulting in more applied education programs (Coman, 2008; Harris \& Gibson, 2008;Mallick \& Chaudhury, 2000; Solomon \& Fernald, 1991). Today there is wide acceptance of the growing importance of university spin-off activity and technology transfer (Bathelt et al. , 2010; Hoye \& Pries, 2009; Hussler et al.,2010; Linton, 2009; Prodan \& Drnovsek, 2010). Although the role of universities is increasingly recognized by governments (Rasmussen, 2008) and perhaps less so by business media (Linton, 2010), changes at public universities still occur relatively slowly. Much of the existing research in this area examines the interaction between the university and industry, or research commercialization at the university level. Researchers have observed an existence of differentiated tools identified for technology transfer at the regional level (Hussler et al., 2010), as well as a variety of business models available to transfer an innovation from the academic world to the practitioner realm (Pries \& Guild, 2010). Some researchers focus on the academic inventor, their intentions (Prodan \& Drnovsek, 2010), or their propensity to reengage in commercialization (Pries \& Guild, 2010). Others focus on the implementation process (Linton, 2002), management team processes, and access to capital (Braunschweig, 2001; Gurdon \& Samsom, 2010; Macho-Stadler et al., 2008).

The most relevant body of research for understanding entrepreneurship within universities are studies of the university characteristics, and the external (often regulatory) environment within which universities operate. A number of studies focus on the impact of the Bayh-Dole Act on the amount of patenting and licensing by universities in the US (Cockburn \& Henderson, 1998; Lipinski et al., 2008; Mowery et al., 2001; Rafferty, 2008; Wadhwa, 2007). Other researchers have examined changes in patent characteristics (Cockburn \& Henderson, 1998) as well as the cause of rapid growth in university patenting and licensing
(Thursby \& Kemp, 2000). University characteristics that act as obstacles to knowledge transfer have also been identified, especially bureaucracy, and paucity of interdisciplinary research (Bonaccorsi \& Piccaluga, 1994; Krabel, 2018; Martins et al., 2018; Migliori et al., 2017). Entrepreneurship is seen as a solution to these obstacles (Behn, 1998; Coman, 2008; Mwasalwiba, 2010; Picco, 2002), as are different methods of facilitating university technology transfer (Barr \& Kellaris, 2000; Fini et al., 2017; Miranda et al., 2017), and more relationships between universities and industry (Henderson et al., 1998; Todorovic et al., 2011).

Understanding of the nature of entrepreneurship within universities, and how an EO might translate into an advantage for a university is still in its infancy. Studies of university involvement in entrepreneurship related activities have largely focused on commercialization per se, the partners involved, and the methods of knowledge transfer. The dimensions of an EO in public institutions, such as a university, are not necessarily the same as those in private firms. Differences may arise from mission and mandate, and governance structure. Consequently, this study attempts to build a theoretical base, which will contribute to a better understanding of the effect EO and its dimensions are likely to have on engineering departments.

\section{METHOD}

The studies cited in the previous section considered the interaction between universities and industry or the activities within universities - all of which are at the university level of analysis (i.e., the whole organisation). The performance/reward structure, however, as well as faculty interactions aregenerally focused more at the department level (Todorovic, 2011). Consequently, university departments have significant influence on the organizational culture and activities of the faculty in their departments, and as such are the focus of this study.

This study was undertaken in two stages. In the first stage, we initially interviewed fifteen faculty members of the University of Waterloo Faculty of Engineering. The University of Waterloo and the Engineering and Computer Science faculties in particular, have a reputation for being very entrepreneurial (Media, 2002). Next, we interviewed twenty-five faculty members from the 
University of Western Ontario, University of Guelph, and McMaster University. These universities were perceived as representative of Canadian research universities (Media, 2002).

Stage 2 involved the use of focus groups. Three focus groups of 10 to 12 participants each were utilized. Most of the participant are either department / institute chairs or tenured senior professors. At the beginning all the participants were given a chance to write down their opinion on the following question: "If someone stated that a particular university department was very 'entrepreneurial' what would that observation mean to you?" Faculty members were afterward given chance to change their opinions/positions based on the overall discussion.

Items collected from faculty members were summarized, and a representative list of items agreed upon in focus groups. This list was then assigned codes developed from the interviews ("Interview Category"). Following, subject statement ("Subject") was identified for each item, and presented immediately following the Interview category. In order to increase inter-rater reliability, another faculty member was asked to do the same analysis using the same items. The findings of the two faculty members were then synthesized into a single table. That table presents all the items that were agreed upon by all three focus groups, in addition to the two columns discussed earlier. Another table was deduced from the original table, where items were sorted using "Interview Category" column. These columns were organized by frequency of occurrence, where each column contains rows developed from the corresponding "Subject/Source" items.

Study participants were chosen randomly from faculty lists posted in the university web sites. An attempt was made to involve as many department chairs as possible. Department chairs or Centre/Institute directors are analogous to middle managers (or CEOs) in the private sector. The use of CEOs or middle managers as single informants is generally the practice in EO related research (Allen \& McCluskey, 1990; Kwaku, 1996; Nahavand \& Chestech, 1988; Pearce et al., 1997; Ruppel \& Harrington, 2000). Hambrick(1981) showed that CEOs' and managers' perceptions were a closer set of objective measures of the same phenomenon than were those of an organization's other members. Approximately $40 \%$ of respondents were department chairs or centre/institute directors.

\section{FINDINGS}

In order to provide as comprehensive discussion of our study as possible, the findings section herein is presented in two stages: Stage 1 and Stage 2

\section{Stage 1}

The respondents placed the greatest emphasis on the outcomes of entrepreneurship, followed by the current strategic emphasis of the university. Of the individual codes, spin-off companies and technology transfer were most frequently mentioned as significant indicators of an entrepreneurial department. The participants appeared to focus on the present situation, and describe the desired outcome, incorporating people and organizational culture as the variables moderating the process. The main themes aggregated from the data are the outcomes of entrepreneurship, organizational culture, people, and current strategic emphasis, which are discussed in the following sections.

\section{Outcomes}

Ten codes were aggregated together into the theme of outcomes of entrepreneurship. The codes in this theme look at attracting entrepreneurial students and faculty to the university, as well as increasing involvement with the private sector - including both consulting and technology transfer. There is a sense of the university starting something new, and this is often associated with spin-off companies. This code had the most text unit references. Finally, the theme also suggests an applied approach to research problem selection as well as an increase in grants and funding available to the university. For example, many participants listed a high number of patents, or business start-ups as evidence of an entrepreneurial department.

\section{Organizational Culture}

Common code pointed towards a need to create a "proper" organizational culture inside the university as well as being "forward thinking". These two characteristics were mentioned as 'requirements' of an entrepreneurial department. Another code in the organizational culture theme deals with the attitude found within the university, including that of the employees and of the administration. Finally, taking risks and having a supportive university vision and mission were 
perceived as crucial to entrepreneurship. For example, one participant stated, "it is hard to be entrepreneurial if this [entrepreneurial behaviour] is looked down upon."

\section{People}

The third theme deals with the people at the university. An entrepreneurial department is one with many entrepreneurial and proactive members who are often quick to act on opportunities in their environment. A different code suggests that people in such a department may be selfish. One participant summarized this theme well in saying that "departments are made of people, and to have an entrepreneurial department, you need entrepreneurial faculty". It is necessary to point out that a number of participants indicated that a presence of a significant proportion of "conservative" personnel was perceived as a negative factor.

\section{Current Strategic Emphasis}

Finally, this theme looks at the present state of the university environment, policies and activities of the university. Items point to the need of universities to seek out commercialisation opportunities and company partnerships to take their innovations to the market. A number of intermediary activities were cited, in which the university acts to bring together researchers and industry. Further, there was reference to the university providing institutional support as well as liberal intellectual property policy (i.e., faculty ownership). Institutional support includes support (social and otherwise) within university departments for entrepreneurial activities, and recognising this in the faculty performance review system.

There was a significant amount of disagreement between respondents about how entrepreneurial a university should be. While some felt that university should not be entrepreneurial at all, others argued that entrepreneurial universities are the way of the future. Likewise, while some felt that university should be involved in commercialization and creating new ventures, others argued that it should be entrepreneurial when teaching and educating its student population.

In order to evaluate how the EO dimensions identified in the literature (innovation, proactiveness and risk-taking) relate to the themes identified in the interviews, the four themes were compared to the three EO dimensions. Specific terms reflecting the EO constructs were identified, and codes assigned to the text units containing the relevant terms. Intersections of the four themes and EO dimensions were then extracted. The result of this process is the 131 intersects shown in Table 1. The EO dimensions received different emphases across the four themes. Sixty-eight percent of all references made to innovation were made in the context of the outcome theme. Proactiveness was referred to only on a few occasions, accounting for $8.4 \%$ of the references made to outcomes. Risktaking was mentioned evenly across the four themes.

Table 1: Themes and EO Dimensions Intersects

\begin{tabular}{|l|c|c|c|c|c|}
\hline \multicolumn{1}{|c|}{ Dimension } & Culture & Outcomes & People & $\begin{array}{c}\text { Existing } \\
\text { Situation }\end{array}$ & Total \\
\hline Innovation & 4 & 60 & 6 & 18 & 88 \\
\hline \% of dimension & $4.55 \%$ & $68.18 \%$ & $6.82 \%$ & $20.45 \%$ & $100.00 \%$ \\
\hline \% of theme & $33.33 \%$ & $83.33 \%$ & $31.58 \%$ & $64.29 \%$ & \\
\hline Proactiveness & 1 & 5 & 4 & 1 & 11 \\
\hline \% of dimension & $9.09 \%$ & $45.45 \%$ & $36.36 \%$ & $9.09 \%$ & $100.00 \%$ \\
\hline \% of theme & $8.33 \%$ & $6.94 \%$ & $21.05 \%$ & $3.57 \%$ & \\
\hline Risk-taking & 7 & 7 & 9 & 9 & 32 \\
\hline \% of dimension & $21.88 \%$ & $21.88 \%$ & $28.13 \%$ & $28.13 \%$ & $100.00 \%$ \\
\hline \% of theme & $58.33 \%$ & $9.72 \%$ & $47.37 \%$ & $32.14 \%$ & \\
\hline Vertical totals & 12 & 72 & 19 & 28 & 131 \\
\hline \% of Grand Total & $9.16 \%$ & $54.96 \%$ & $14.50 \%$ & $21.37 \%$ & \\
\hline$\%$ of theme & $100.00 \%$ & $100.00 \%$ & $100.00 \%$ & $100.00 \%$ & \\
\hline
\end{tabular}

These findings were consequently presented in a graphical model presented in Figure 1. As the reader can conclude, above research strongly suggests that Risk-Taking Culture is very important in the beginning of the process, while innovation outcomes are presented more as 
outcomes (rather than ingredients) of the entrepreneurial department. Organizational Culture and People appear to be critical factors promoting the process forward. One needs to remember that risk-taking is likely to be impacted by both the organizational culture and the human factor (people).

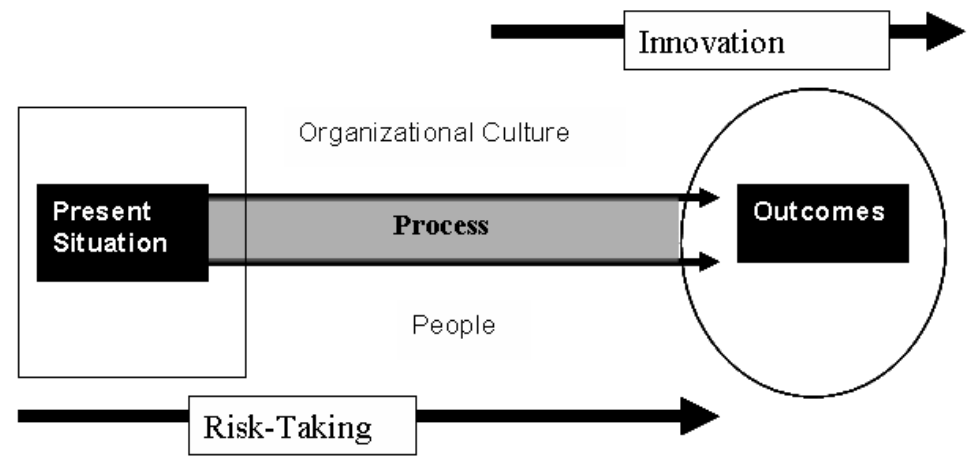

Figure 1: Relationship between Themes and EO Dimensions

\section{Stage 2}

Table 2. presents the list of items agreed upon by the three focus groups as being the most representative of the topic in question, as well as the "Interview Category" and "Subject/Source" items. Table 3 is the reorganization of the said two factors, using frequency as the sorting determinant.

Table 2: Items Signifying Outcomes of EO within University

\begin{tabular}{|c|c|c|}
\hline Items: & $\begin{array}{l}\text { Interview } \\
\text { category }\end{array}$ & Subject/Source \\
\hline University department has close ties to industry & Collaboration & Industry \\
\hline $\begin{array}{l}\text { University department recognized by industry for our entrepreneurial } \\
\text { contributions }\end{array}$ & Recognition & $\begin{array}{l}\text { Entrepreneurial } \\
\text { contributions }\end{array}$ \\
\hline University department significant funding from industry & Funding & Industry funding \\
\hline $\begin{array}{l}\text { Entrepreneurial faculty members bring significant funding to the } \\
\text { department }\end{array}$ & Funding & Funding Sources \\
\hline University department receives funding from many different sources & Funding & Funding Sources \\
\hline University department is highly regarded by media & Reputation & Regarded by Media \\
\hline University department is highly regarded by industry & Reputation & Regarded by Industry \\
\hline $\begin{array}{l}\text { University department collaboration with industry resulted in } \\
\text { significant publications in the department }\end{array}$ & Collaboration & Resulted in research \\
\hline University department industry contacts have resulted in patents & Collaboration & Resulted in Patents \\
\hline $\begin{array}{l}\text { University department faculty members often receive help for their } \\
\text { research from outside the university }\end{array}$ & Collaboration & Help with research \\
\hline $\begin{array}{l}\text { Increased department funding resulted from our partnership with } \\
\text { industry }\end{array}$ & Funding & Industry partnership \\
\hline $\begin{array}{l}\text { University department graduate students are considered among the } \\
\text { best }\end{array}$ & Grad students & $\begin{array}{l}\text { Students considered the } \\
\text { best }\end{array}$ \\
\hline Industry is highly motivated to hire our graduates & Grad students & Students hired \\
\hline Our faculty members are often mentioned in the media & Faculty & Media mentions \\
\hline $\begin{array}{l}\text { Significant proportion of our faculty members made a substantial } \\
\text { contribution to industry }\end{array}$ & Faculty & Industry contribution \\
\hline University department is often approached by industry & department & Approached by industry \\
\hline $\begin{array}{l}\text { University department research has resulted in a high number of } \\
\text { patents (compared to other similar departments) }\end{array}$ & Department & High number of patents \\
\hline $\begin{array}{l}\text { New ideas generated by faculty members often result in financial gains } \\
\text { for our department }\end{array}$ & Department & $\begin{array}{l}\text { Department finance } \\
\text { gains }\end{array}$ \\
\hline University department funding has increased in last few years & Funding & Funding increased \\
\hline
\end{tabular}


Table 2: Items Signifying Outcomes of EO within University (extension)

\begin{tabular}{|l|l|l|}
\hline \multicolumn{1}{|c|}{ Items: } & \multicolumn{1}{|c|}{$\begin{array}{c}\text { Interview } \\
\text { category }\end{array}$} & \multicolumn{1}{|c|}{ Subject/Source } \\
\hline We often have Start-ups result from research & Start-ups & Start-ups from Research \\
\hline $\begin{array}{l}\text { University department has a high number of industry partnership } \\
\text { agreements }\end{array}$ & Collaboration & $\begin{array}{l}\text { High number of } \\
\text { Industry partnerships }\end{array}$ \\
\hline University department has very high faculty retention rates & Faculty & High Retention Rates \\
\hline $\begin{array}{l}\text { University department has a high number of industry licensing } \\
\text { agreements }\end{array}$ & Collaboration & $\begin{array}{l}\text { High number of } \\
\text { Licensing Agreements }\end{array}$ \\
\hline University department has significant influence within the university & Reputation & $\begin{array}{l}\text { Department Influence } \\
\text { in University }\end{array}$ \\
\hline University department Students set up their own companies & Startup & Student Start-up \\
\hline University department Faculty set up their own companies & Startup & Faculty Start-ups \\
\hline
\end{tabular}

Table 3: Items Organized by Category

\begin{tabular}{|c|c|c|c|c|c|c|}
\hline Collaboration & Funding & Reputation & Department & Faculty & Start-ups & $\begin{array}{c}\text { Grad } \\
\text { students }\end{array}$ \\
\hline $\begin{array}{l}\text { Help with } \\
\text { research }\end{array}$ & $\begin{array}{l}\text { Funding } \\
\text { increased }\end{array}$ & $\begin{array}{l}\text { Entrepreneuria } \\
1 \text { contributions }\end{array}$ & $\begin{array}{l}\text { Approached } \\
\text { by industry }\end{array}$ & $\begin{array}{l}\text { High } \\
\text { Retention } \\
\text { Rates }\end{array}$ & $\begin{array}{l}\text { Faculty Start- } \\
\text { ups }\end{array}$ & $\begin{array}{l}\text { Students } \\
\text { considered the } \\
\text { best }\end{array}$ \\
\hline $\begin{array}{l}\text { High number } \\
\text { of Industry } \\
\text { partnerships }\end{array}$ & $\begin{array}{l}\text { Funding } \\
\text { Sources }\end{array}$ & $\begin{array}{l}\text { Department } \\
\text { Influence in } \\
\text { University }\end{array}$ & $\begin{array}{l}\text { Department } \\
\text { finance gains }\end{array}$ & $\begin{array}{l}\text { Industry } \\
\text { contribution }\end{array}$ & $\begin{array}{l}\text { Student Start- } \\
\text { up }\end{array}$ & Students hired \\
\hline $\begin{array}{l}\text { High number } \\
\text { of Licensing } \\
\text { Agreements }\end{array}$ & $\begin{array}{l}\text { Funding } \\
\text { Sources }\end{array}$ & $\begin{array}{l}\text { Regarded by } \\
\text { Industry }\end{array}$ & $\begin{array}{l}\text { High number } \\
\text { of patents }\end{array}$ & $\begin{array}{l}\text { Media } \\
\text { mentions }\end{array}$ & $\begin{array}{l}\text { Start-ups from } \\
\text { Research }\end{array}$ & \\
\hline Industry & $\begin{array}{l}\text { Industry } \\
\text { funding }\end{array}$ & $\begin{array}{l}\text { Regarded by } \\
\text { Media }\end{array}$ & & & & \\
\hline $\begin{array}{l}\text { Resulted in } \\
\text { Patents }\end{array}$ & $\begin{array}{l}\text { Industry } \\
\text { partnership }\end{array}$ & & & & & \\
\hline $\begin{array}{l}\text { Resulted in } \\
\text { research }\end{array}$ & & & & & & \\
\hline
\end{tabular}

Table 3 presents a clearer visual of the observations made by the investigators. Participants perceive a more entrepreneurial University Engineering department to be one that first and foremost results in high level of collaboration with off-campus stakeholders mainly industry. In fact, current literature also seems to support industry collaboration as one of the variables of interest (Abouzar \& Moshabaki, 2011; Martín-Roja et al., 2011).

Next, this study supports the notion that an entrepreneurial engineering department is one that will gain in funding and reputation. This notion is further supported by the column titled "Department" which mentions both collaboration with the industry and financial gain for the department. This is in agreement with Dooley and Kirk (Dooley \& Kirk 2007) who presents a need for research universities to "to engage successfully in collaborative research with industry partners" (p. 316).
Remaining columns in Table $3 \mathrm{~b}$ seem to suggest that such an entrepreneurial engineering university department will stand the benefit internal stakeholders such as the faculty and students. This benefit is presented in both the traditional innovation measures such as "start-ups and "patents and licensing" as well as some less traditional matrices. In fact, study results are suggesting that, contrary to some concerns presented to the opposite, the overall education quality, and thus university reputation, will also increase. Indeed, having an entrepreneurial department will go a long way towards enriching entrepreneurship education, and overall education within the university (Edelman et al., 2008; Jones \& Iredale, 2010; Mwasalwiba, 2010).

\section{CONCLUSION}

While the importance of entrepreneurship is well recognized in the private sector, increasingly large public organizations, such as universities, are turning towards entrepreneurship in their efforts to 
regenerate and rejuvenate themselves. This study examined a crucial question: What constitutes an entrepreneurial university department (in this case engineering), through personal interview of 40 faculty members at four different universities, followed by three focus groups. The research reported in this paper addressed the extent to which these dimensions characterize the notion of entrepreneurship within universities.

Analysis of forty open-ended interviews with faculty members found four themes that distinguish entrepreneurial departments: organizational culture, outcomes of entrepreneurship, people and current emphasis. Intersections with the dimensions of an EO show some associations, especially between innovation and outcomes, and risk-taking and all four themes. A graphic model summarises the results, and posits that risk-taking may be the most important dimension in developing an entrepreneurial university. Innovativeness is more closely associated with entrepreneurial outcomes and results.

Results of focus group study support the notion that entrepreneurship is beneficial to engineering departments and faculties. In fact, entrepreneurial departments will enrich their collaboration with industry as well as increase department funding and reputation. Equally important, this study shows strong support for the notion that all department's internal stakeholders (faculty, staff and students) will also benefit from its entrepreneurial posture.

This study also has practical significance. While it is popular to emphasize innovation in universities, our findings suggest that it is crucial to have a risk tolerant environment, and to develop the right organizational culture and people to support this. Likewise, this study also shows that engineering departments cannot do this alone. Instead, by collaborating with industry, engineering departments will grow in reputation and financial wellbeing, while at the same time enriching their own faculty, staff and students.

\section{LIMITATIONS AND FUTURE RESEARCH}

Although this study provides interesting results, the generalizability of these results is limited by the sample size. Consequently, this study needs be followed by a more comprehensive analysis that examines the concepts presented herein in more detail. This should include a more comprehensive empirical evaluation which would employ statistical techniques (e.g., exploratory factor analysis, structural equation modelling) as suggested by Churchill (1979).

This study has a number of limitations, of which the greatest is the sample size. A sample of forty interviews, and three focus groups is adequate for gaining a general understanding of the issues, but there is a need to conduct a larger study to explore further the issues identified. The use of a single question, coupled with a small sample size is another source of limitation. Although other questions were also used to supplement the main question in this study, there is a need to further research entrepreneurship at university, and define more precisely the role entrepreneurship plays in post-secondary educational institutions.

\section{REFERENCES}

Abouzar, Z., \& Moshabaki, A. (2011). Measuring university performance using a knowledge-based balanced scorecard. International Journal of Productivity and Performance Management, 60(8), 824-843.

Abramo, G., D'Angelo, C. A., Di Costa, F., \& Solazzi, M. (2009). University-industry collaboration in Italy: A bibliometric examination. Technovation, 29(6/7), 498-507.

Agrawal, A. (2001). University-to-industry knowledge transfer: literature review and unanswered question. International Journal of Management Reviews, 3(4), 285-302.

Allen, D. A., \& McCluskey, R. (1990). Structure, Policy, Services and Performance in the Business Incubator Industry. Entrepreneurship, Theory and Practice, 15(2), 61-77.

Association of Universities and Colleges of Canada. (1998). The Economic Impact of University Research. Ottawa, Canada: Association of Universities and Colleges of Canadao. Document Number)

Association of Universities and Colleges of Canada. (2001a). Background Report on the Facilities and Institutional Support Costs Incurred by Canadian Universities in conducting Federally Sponsored Research. Ottawa, Canada: Association of Universities and Colleges of Canadao. Document Number)

Association of Universities and Colleges of Canada. (2001b). Commercialization of University Research. Ottawa, Canadao. Document Number)

Association of University Technology Managers. (2000). AUTM Licensing Survey: FY 1999, Survey Summary. Northbrook, IL: Association of University Technology Managerso. Document Number) 
Baldini, N. (2010). Do royalties really foster university patenting activity? An answer from Italy. Technovation, 30(2), 109-116.

Barr, T. F., \& Kellaris, J. J. (2000). Susceptibility to Advertising; An Individual Difference with Implications for the Processing of Persuasive Messages. Advances in Consumer Research, 27(1), 230-234.

Bathelt, H., Kogler, D. F., \& Munro, A. K. (2010). A knowledge-based typology of university spin-offs in the context of regional economic development. Technovation, 30(9/10), 519-532.

Behn, R. D. (1998). What right do public managers have to lead? Public Administration Review, 58(3), 209-217.

Berggren, E., \& Dahlstrand, S. (2009). Creating an Entrepreneurial Region: Two Waves of Academic Spin-offs from Halmstad University. European Planning Studies, 17(8), 1171-1189.

Bonaccorsi, A., \& Piccaluga, A. (1994). A Theoretical Framework for the Evaluation of University Industry Relationship. $R$ \& D Management, 24(3), 229-245.

Box, R. C. (1999). Running government like a business: Implications for public administration theory and practice. American Review of Public Administration, 29(1), 19-43.

Braunschweig, C. (2001). Entrepreneurship: VCs and Universities Work to Make it An Academic Goal. Venture Capital Journal, 41(10), N.PAG.

Bray, M. J., \& Lee, J. N. (2000). University Revenues from Technology Transfer: Licensing Fees v.s. Equity Positions. Journal of Business Venturing, 15(5/6), 385-392.

Churchill, G. A. (1979). A Paradigm for Developing Better Measures of Marketing Constructs. Journal of Marketing Research, 16(1), 64-74.

Cockburn, I. M., \& Henderson, R. M. (1998). Absorptive capacity, coauthoring behavior, and the organization of research in drug discovery. The Journal of Industrial Economics, 46(2), 157-183.

Coman, A. (2008). Education and entrepreneurship: Drivers for sustainable development. Human Systems Management, 27(3), 255-260.

Conceicao, P., Heitor, M. V., \& Oliveira, P. (1998). University-based technology licensing in the knowledge based economy. Technovation, 18(10), 615-625.

Coulthard, M. (2007). The role of entrepreneurial orientation on firm Performance and the potential influence of relational dynamism. Journal of Global Business and Technology, 3(1), 29-39.

Dooley, L., \& Kirk, D. (2007). University-industry collaboration. European Journal of Innovation Management, 10(3), 316-333.

Edelman, L. F., Manolova, T. S., \& Brush, C. G. (2008). Entrepreneurship Education: Correspondence Between Practices of Nascent Entrepreneurs and Textbook Prescriptions for
Success. Academy of Management Learning \& Education, 7(1), 56-70.

Etemad, H., \& Wright, R. W. (1999). Internationalization of SMEs: Management responses to a changing environment. Journal of International Marketing, 7(4), 4-10.

Expert Panel on the Commercialization of University Research. (1999). Public Investments in University Research: Reaping the Benefits. Ottawa, Ontario: Advisory Council on Science and Technologyo. Document Number)

Fini, R., Fu, K., Mathisen, M. T., Rasmussen, E., \& Wright, M. (2017). Institutional determinants of university spin-off quantity and quality: a longitudinal, multilevel, cross-country study. Small Business Economics, 48(2), 361-391.

Gurdon, M. A., \& Samsom, K. J. (2010). A longitudinal study of success and failure among scientist-started ventures. Technovation, 30(3), 207-214.

Hambrick, D. C. (1981). Strategic Awareness Within Top Management Teams. Strategic Management Journal., 2(3), 263-280.

Harris, M. L., \& Gibson, S. G. (2008). Examining the entrepreneurial attitudes of US business students. Education \& Training, 50(7), 568-581.

Henderson, R., Jaffe, A. B., \& Trajtenberg, M. (1998). Universities as a source of commercial technology: A detailed analysis of university patenting, 19651988. The Review of Economics and Statistics, 80(1), 119-127.

Hernandez-Gantes, V. M., Sorensen, R., \& Nieri, A. (1996). Fostering Entrepreneurship Through Business Incubation: The Role and Prospects of Postsecondary Vocational - Technical Education. Report 1: Incubator Clients and Managers (MDS893): Centre on Education and Work, University of Wisconsin - Madisono. Document Number)

Hoye, K., \& Pries, F. (2009). 'Repeat commercializers,' the 'habitual entrepreneurs' of university-industry technology transfer. Technovation, 29(10), 682-689.

Hussler, C., Picard, F., \& Tang, M. F. (2010). Taking the ivory from the tower to coat the economic world: Regional strategies to make science useful. Technovation, 30(9/10), 508-518.

Johnson, D., \& Tilley, F. (1999). HEI and SME linkages: Recommendations for the future. International Small Business Journal, 17(4), 66-81.

Johnson, W. H. A. (2008). Roles, resources and benefits of intermediate organizations supporting triple helix collaborative R\&D: The case of Precarn. Technovation, 28(8), 495-505.

Jones, B., \& Iredale, N. (2010). Enterprise education as pedagogy. Education \& Training, 52(1), 7-19.

Kolympiris, C., \& Klein, P. G. (2017). The Effects of Academic Incubators on University Innovation. Strategic Entrepreneurship Journal, 11(2), 145-170.

Krabel, S. (2018). Are entrepreneurs made on campus? The impact of entrepreneurial universities and graduates human capital on graduates occupational 
choice. Journal of International Entrepreneurship, 16(4), 456-485.

Kropp, F., Lindsay, N., \& Shoham, A. (2008). Entrepeneurial Orientation and International Entrepreneurial Business Venture Startup. International Journal of Entrepreneurial Behaviour \& Research, 14(2), 102-117.

Kwaku, A.-G. (1996). Differential potency of factors affecting innovation performance in manufacturing and services firms in Australia. The Journal of Product Innovation Management, 13(1), 35-53.

Lasrado, V., Sivo, S., Ford, C., O'Neal, T., \& Garibay, I. (2016). Do graduated university incubator firms benefit from their relationship with university incubators? Journal of Technology Transfer, 41(2), 205-219.

Lee, J., \& Slater, J. (2007). Dynamic capabilities, entrepreneurial rent-seeking and the investment development path: The case of Samsung. Journal of International Management, 13(3), 241-257.

Lekmat, L., Selvarajah, C., \& Hewege, C. (2018). Relationship between Market Orientation, Entrepreneurial Orientation, and Firm Performance in Thai SMEs: The Mediating Role of Marketing Capabilities. International Journal of Business and Economics, 17(3), 213.

Li, Y., Zhao, Y., Tan, J., \& Liu, Y. (2008). Moderating Effects of Entrepreneurial Orientation on Market Orientation-Performance Linkage: Evidence from Chinese Small Firms. Journal of Small Business Management, 46(1), 113-133.

Linton, J. D. (2002). Implementation research: state of the art and future directions. Technovation, 22(2), 65-79.

Linton, J. D. (2009). Technology innovation management's growing influence and impact. Technovation, 29(10), 643-644.

Linton, J. D. (2010). How do technology innovation management journals stack up against the Financial Times 45 - impressively - and other notes. Technovation, 30(9/10), 483-484.

Lipinski, J., Minutolo, M. C., \& Crothers, L. M. (2008). The Complex Relationship Driving Technology Transfer: The Potential Opportunities Missed by Universities. Journal of Behavioral and Applied Management, 9(2), 112-134.

Liu, Y. (2017). Born global firm's growth and collaborative entry mode: the role of transnational entrepreneurs. International Marketing Review, 34(1), 46-67.

Macho-Stadler, I., Pérez-Castrillo, D., \& Veugelers, R. (2008). Designing Contracts for University Spinoffs. Journal of Economics \& Management Strategy, 17(1), 185-218.

Mallick, D. N., \& Chaudhury, A. (2000). Technology Management Education in MBA Programs: a Comparative Study of Knowledge and Skill Requirements. Journal of Engineering and Technology Management, 17(2), 153-173.
Martín-Rojas, R., García-Morales, V. J., \& GarcíaSánchez, E. (2011). The influence on corporate entrepreneurship of technological variables. Industrial Management + Data Systems, 111(7), 984-1005.

Martins, I., Juan Pablo Pérez, M., \& Andres Velásquez, M. (2018). Self-confidence and fear of failure among university students and their relationship with entrepreneurial orientation. Academia, 31(3), 471-485.

Media, T. R. (2002). Maclean's universities : measuring excellence : an insider's guide. Maclean's Magazine, annual.

Mian, S. A. (1994). US University - Sponsored technology incubators: an overview of management, policy and performance. Technovation, 14(8), 515528.

Mian, S. A. (1996). Assessing Value - added contributions of university technology business incubators to tenant firms. Research Policy, 25(3), 325-335.

Mian, S. A. (1997). Assessing and Managing the University Technology Business Incubator: An Integrative Framework. Journal of Business Venturing, 12(4), 251-285.

Migliori, S., Pittino, D., Consorti, A., \& Lucianetti, L. (2017). The relationship between Entrepreneurial Orientation, Market Orientation and Performance in University Spin-Offs. International Entrepreneurship and Management Journal, 1-22.

Miles, R. E., \& Snow, C. C. (1978). Organizational Strategy, Structure, and Process. Toronto: McGrawHill Book Company.

Miller, D. (1983). The Correlates of Entrepreneurship in Three Types of Firms. Management Science, 29(7), 770-792.

Mintzberg, H. (1973). Strategy-Making in Three Modes. California Management Review, 16(000002), 44-53.

Miranda, F. J., Chamorro, A., \& Rubio, S. (2017). Rethinking university spin-off: a critical literature review and a research agenda. Journal of Technology Transfer, 43(4), 1007-1038.

Mishra, C. S. (2017). Entrepreneurial Orientation. Entrepreneurship Research Journal, 7(4), 99-120.

Morgan, R. E., \& Strong, C. A. (2003). Business performance and dimensions of strategic orientation. Journal of Business Research, 56(3), 163-176.

Morris, M. H., \& Jones, F. F. (1999). Entrepreneurship in established organizations: The case of the public sector. Entrepreneurship Theory and Practice, 24(1), 71-91.

Morris, M. H., \& Paul, G. W. (1987). The Relationship Between Entrepreneurship and Marketing in Established Firms. Journal of Business Venturing, 2(3), 247-260.

Mowery, D. C., Nelson, R. R., \& Sampat, B. N. (2001). The Growth of Patenting and Licensing by U.S. Universities: An assessment of the effects of the Boyh-Dole Act of 1980. Research Policy, 30(1), 99119. 
Mudalige, D., Noor Azizi, I., \& Marlin Abdul, M. (2018). Exploring the Role of Individual Level and Firm Level Dynamic Capabilities in SMEsâ€тм Internationalization. Journal of International Entrepreneurship, 1-34.

Mustar, P., \& Wright, M. (2010). Convergence or path dependency in policies to foster the creation of university spin-off firms? A comparison of France and the United Kingdom. Journal of Technology Transfer, 35(1), 42-65.

Mwasalwiba, E. S. (2010). Entrepreneurship education: a review of its objectives, teaching methods, and impact indicators. Education \& Training, 52(1), 2047.

Nahavand, A., \& Chestech, S. (1988). The Impact of Consulting on Small Business: A further examination. Entrepreneurship, Theory and Practice, 13(1), 29-40.

Naldi, L., Nordqvist, M., Sjoerg, K., \& Wiklund, J. (2007). Entrepreneurial Orientation, Risk Taking, and Performance in Family Firms. Family Business Review, 20(1), 33-47.

National Governors Association. (2000). Nurturing Entrepreneurial Growth in State Economies. Washington, D.C.: National Governors Associationo. Document Number)

Nosella, A., \& Grimaldi, R. (2009). University-level mechanisms supporting the creation of new companies: an analysis of Italian academic spin-offs. Technology Analysis \& Strategic Management, 21(6), 679-698.

Paweta, E. (2015). Entrepreneur-related Constructs Explaining the Emergence of Born Global Firms: A Systematic Literature Review. Entrepreneurial Business and Economics Review, 3(4), 11-36.

Pearce, J., Kramer, A. I., Robertson, T., \& Robbins, D. K. (1997). Effects of managers' entrepreneurial behavior on subordinates. Journal of Business Venturing, 12(2), 147-160.

Perkmann, M., \& Walsh, K. (2008). Engaging the scholar: Three types of academic consulting and their impact on universities and industry. Research Policy, 37(10), 1884.

Picco, G. (2002). Balancing bureaucracy and the individual: Institutional reform and peace operations. Journal of International Affairs, 55(2), 235-244.

Pries, F., \& Guild, P. (2010). Commercializing inventions resulting from university research: Analyzing the impact of technology characteristics on subsequent business models. Technovation, 30(Artcile in Press.), 151-160.

Prodan, I., \& Drnovsek, M. (2010). Conceptualizing academic-entrepreneurial intentions: An empirical test. Technovation, 30(5/6), 332-347.

Rafferty, M. (2008). The Bayh-Dole Act and university research and development. Research Policy, 37(1), 29-40.
Rainsford, P. (1992). The Small Business Institute: Hands-On Learning. Cornell Hotel and Restaurant Administration Quarterly, 33(4), 73-77.

Rasmussen, E. (2008). Government instruments to support the commercialization of university research: Lessons from Canada. Technovation, 28(8), 506-517.

Richard, O. C., Barnett, T., Dwyer, S., \& Chadwick, K. (2004). Cultural diversity in management, firm performance, and the moderating role of entrepreneurial orientation dimensions. Academy of Management Journal, 47(2), 255-266.

Ruppel, C. P., \& Harrington, S. J. (2000). The relationship of communication, ethical work climate, and trust to commitment and innovation. Journal of Business Ethics, 25(4), 313-328.

Schneider, B., Wheeler, J. K., \& Cox, J. F. (1992). A passion for service: Using content analysis to explicate service climate themes. Journal of Applied Psychology, 77(5), 705-716.

Solomon, G. T., \& Fernald, L. (1991). Trends in Small Business Management and Entrepreneurship Education in the United States. Entrepreneurship, Theory and Practice, 15(3), 25-39.

Steffensen, M., Rogers, E., \& Speakman, K. (2000). Spin-offs from Research Centers at a Research University. Journal of Business Venturing, 15(1), 93-111.

Stevenson, J. C., \& Thomas, M. W. (2001). USC's Technology Incubator. Business \& Economic Review, 47(2), 11-14.

Thursby, J. G., \& Kemp, S. (2000). What do we say about ourselves and what does it mean? Yet another look at economics department research. Journal of Economic Literature, 38(2), 383-404.

Todorovic, Z. W., McNaughton, R. B., \& Guild, P. (2011). ENTRE-U: An entrepreneurial orientation scale for universities. Technovation, 31(2/3), 128137.

van Burg, E., Romme, A. G. L., Gilsing, V. A., \& Reymen, I. M. M. J. (2008). Creating University Spin-Offs: A Science-Based Design Perspective. The Journal of Product Innovation Management, 25(2), 114-129.

Wadhwa, V. (2007, 2007/06/18/). Universities: Get Entrepreneurial. BusinessWeek Online BusinessWeek Online J1 - BusinessWeek Online, 20-20.

Wiklund, J. (1999). The sustainability of the entrepreneurial orientation--performance relationship. Entrepreneurship: Theory \& Practice, 24(1), 39-50.

Wolf, G. (2017). Entrepreneurial university: a case study at Stony Brook University. The Journal of Management Development, 36(2), 286-294. 


\section{ORIJENTACIJA KA PREDUZETNIŠTVU NA INŽENJERSKIM DEPARTMANIMA: DISKUSIJA!}

Koncept "preduzetničke orijentacije" je dobro utvrđen u literaturi o strateškom položaju preduzeća. Velike organizacije se sve više okreću preduzetništvu u svojim naporima da postanu fleksibilne i da odgovore na pritiske da "učine više sa manje". Da bi shvatili šta to znači da su inženjerski departmani ,preduzetnički“, sprovedeni su intervjui sa četrdeset članova fakulteta. Transkripti intervjua su analizirani korišćenjem softvera za analizu sadržaja. Zatim, izabrane su interesne grupe radi utvrđivanja validnosti razvijenih elemenata. Rezultati ukazuju na to da je preuzimanje rizika najvažnija dimenzija u razvoju departmana za preduzetnički inženjering i neophodnost za njenom kontinuiranom konkurentnošću. Dalje, studija takođe podržava ideju da će preduzetnički inženjerski fakultet razviti viši nivo saradnje, finansiranja i ugleda u industriji - što će dovesti do većeg uspeha za interne univerzitetske aktere.

Key words: Univerzitetsko preduzetništvo, Preduzetnička orijentacija, Univerzitetski departman. 